\begin{tabular}{|c|c|}
\hline Title & Multiple A utoimmune Diseases after A utol ogous Stem-Cell Transplantation \\
\hline Author(s) & Bohgaki, Toshiyuki; A tsumi, T atsuy a; Koike, Takao \\
\hline Citation & $\begin{array}{l}\text { New England Journal of Medicine, 357(26), } 27342736 \\
\text { https://doi.org/10.1056/NEJMc076383 }\end{array}$ \\
\hline Issue Date & $2007-12-27$ \\
\hline Doc URL & http:/hdl.handle.net/2115/62849 \\
\hline Rights & $\begin{array}{l}\text { From New England Journal of Medicine, Bohgaki, T., A tsumi, T., Koike, T., Multiple A utoimmune Diseases after } \\
\text { A utologous Stem-Cell Transplantation, V olume } 357 \text { No. 26, pp. } 2734 \text { 2736. Copyright @ } 2007 \text { Massachusetts Medical } \\
\text { Society. Reprinted with permission. }\end{array}$ \\
\hline Type & article \\
\hline File Information & 15_nejmc076383.pdf \\
\hline
\end{tabular}

Instructions for use 


\section{Multiple Autoimmune Diseases after Autologous Stem-Cell Transplantation}

TO THE EDITOR: Hematopoietic stem-cell transplantation can be an effective treatment in patients with refractory systemic sclerosis. ${ }^{1}$ We report on a 19-year-old woman with systemic sclerosis who underwent CD34+-selected autologous hematopoietic stem-cell transplantation in March 2001. Before the transplantation, the physical and laboratory findings showed no evidence of any other autoimmune diseases. After written consent was obtained from the patient, CD34+ hematopoietic stem cells were transplanted according to a method used for systemic sclerosis. ${ }^{1}$ The dermal sclerosis improved immediately after transplantation, but thrombocytopenia and Graves' disease developed.

In June 2005, the patient was admitted to the

Figure 1 (facing page). Clinical and Laboratory Findings after CD34+-Selected Autologous Hematopoietic Stem-Cell Transplantation. Panel A shows the association between clinical events (including the onset of autoimmune thrombocytopenia [AITP], Graves' disease, systemic edema, and cerebral infarction) and changes in titers of each autoantibody. At the onset of edema, a serum sample from the patient contained anti-Sm, anti-Scl70, and anticardiolipin IgG antibodies (IgG-aCL), in addition to anti-DNA autoantibodies and lupus anticoagulant. The solid line indicates the modified Rodnan total skin thickness score (ranging from 0 to 51 , with higher values indicating more thickness). Normal ranges for these levels are as follows: anti-Sm, 0 to $5.9 \mathrm{U}$ per milliliter, anti-Scl70, 0 to $18.9 \mathrm{U}$ per milliliter; and IgG-aCL, <1.3 U per milliliter. Panel B shows serum levels of interleukin-17, transforming growth factor $\beta 1$ (TGF- $\beta 1$ ), and interleukin- 6 . Normal ranges for these levels are as follows: TGF- $\beta 1,30.95$ to $38.65 \mathrm{ng}$ per milliliter; interleukin-6, 0.54 to $1.10 \mathrm{ng}$ per milliliter; and interleukin-17, not detected. Panel C shows changes in T cells, including the ratio of interferon- $\gamma$-producing CD4+ T cells (Thl) and interleukin-4-producing CD4+ T cells (Th2) and FOXP3 messenger RNA (mRNA) on peripheral-blood mononuclear cells. The solid squares indicate levels of CD19+ cells, and the circles indicate levels of CD4+CD25+ cells. Normal ranges are as follows: ratio of Thl to Th2, 7.22 to 47.52; FOXP3 mRNA, 57.10 to 175.19 copies per glyceraldehyde-3-phosphate dehydrogenase (GAPDH) standard; CD19+, 9.24 to $17.01 \%$; and CD4+CD25+, 5.66 to $10.24 \%$. Calculations were made with the JMP statistical software package, version 5.0 (SAS Institute). 


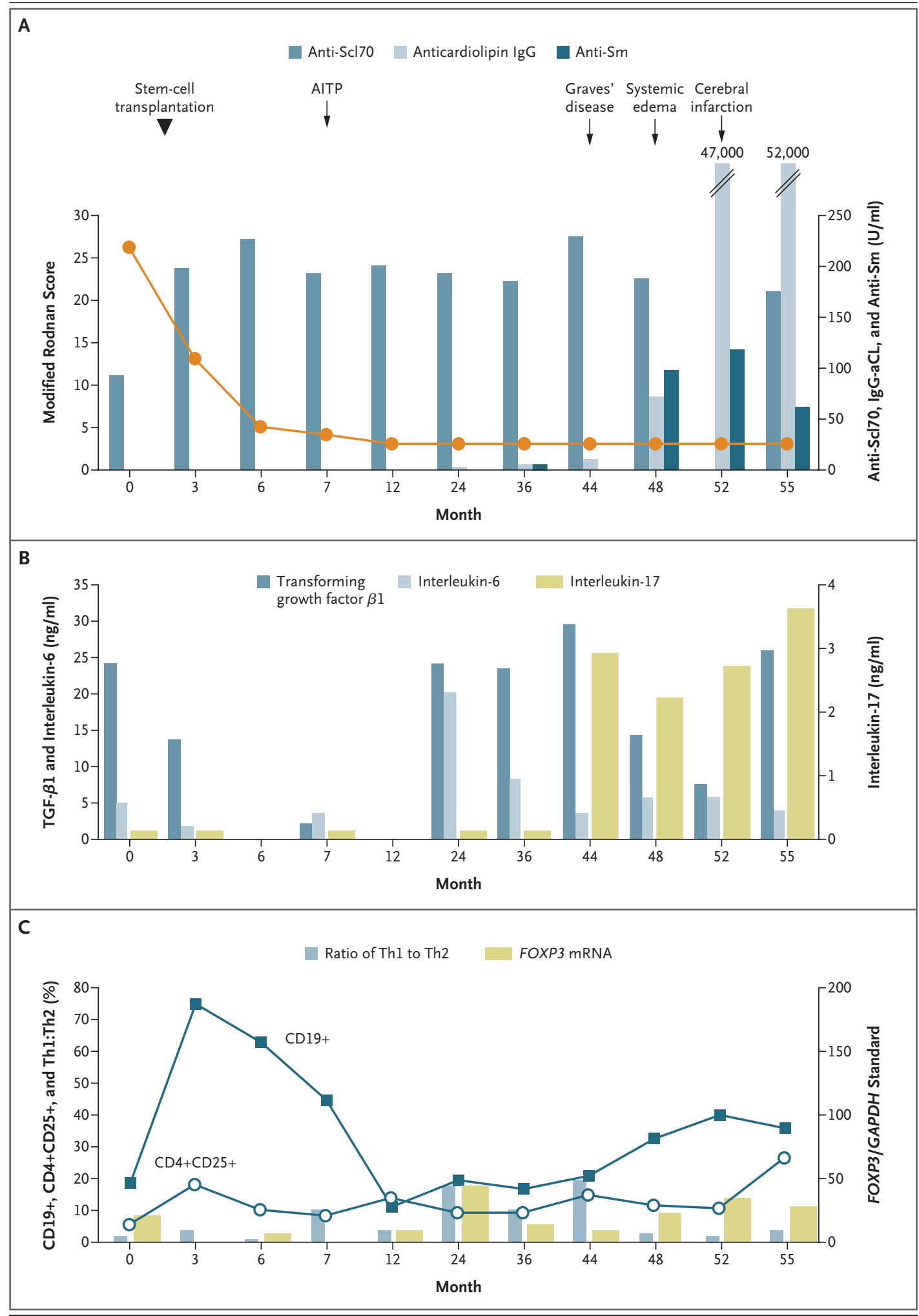

N ENGLJ MED 357;26 WWW.NEJM.ORG DECEMBER 27, 2007

The New England Journal of Medicine 


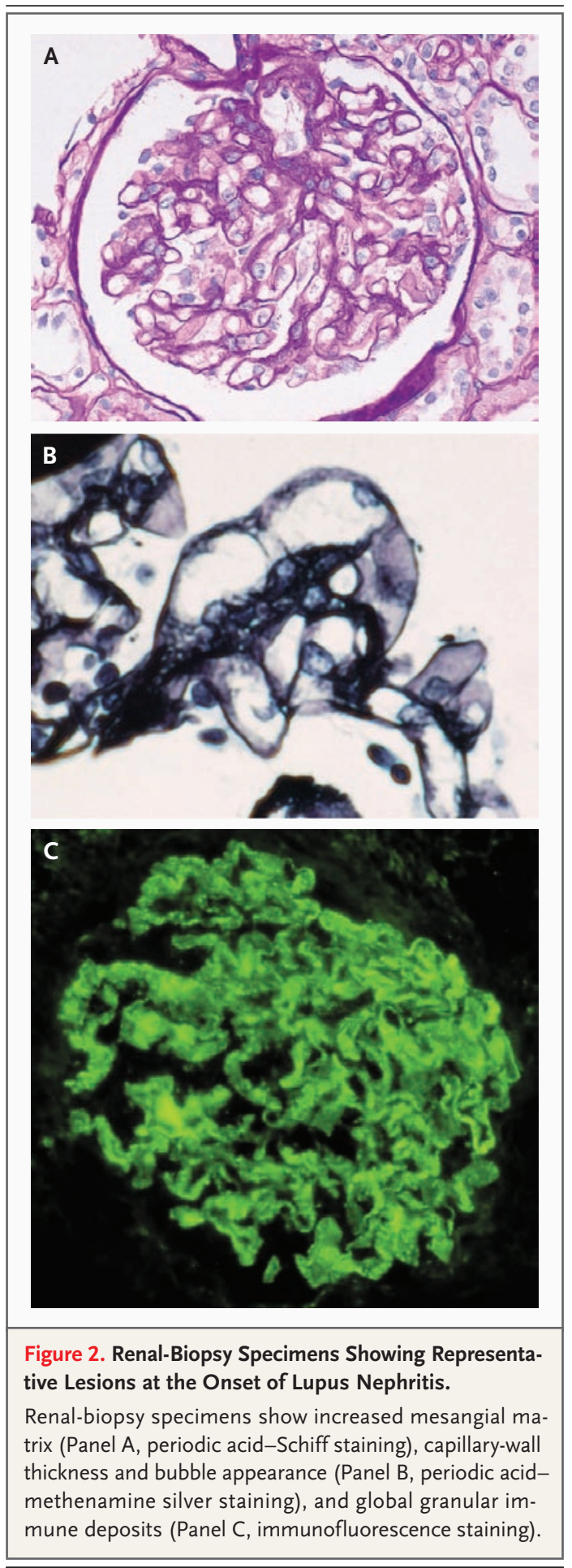

hospital because of fever and edema. Blood tests revealed proteinuria (11.4 g per day) and new autoantibodies in the serum (Fig. 1A). On the sixth hospital day, paralysis developed on the left side as the result of a right cerebral infarction. Systemic lupus erythematosus with membranoustype lupus nephritis (Fig. 2) and the antiphospholipid-antibody syndrome were diagnosed; the patient was treated with prednisolone, warfarin, and cyclosporine. She is currently in clinical remission and is back at work.

During the early phases of immune reconstitution, residual lymphocytes undergo proliferation and expansion, a process controlled by regulatory $\mathrm{T}$ cells. ${ }^{2,3}$ These cells, defined by the phenotype $\mathrm{CD} 4+\mathrm{CD} 25+\mathrm{FOXP3}+$, are important in the prevention of autoimmunity. Interleukin17-producing helper $\mathrm{T}$ (Th17) cells may play a role in the induction of autoimmunity. 4,5 In our patient, the level of serum interleukin-17, released mainly by Th17 cells, was elevated at the onset of the systemic lupus (Fig. 1B). Levels of FOXP3 messenger RNA, a marker of regulatory $\mathrm{T}$ cells, were reduced, suggesting a deficiency of such cells (Fig. 1C). The findings in our patient suggest a role of both regulatory $\mathrm{T}$ cells and Th17 in the development of systemic lupus.

Toshiyuki Bohgaki, M.D., Ph.D.

Tatsuya Atsumi, M.D., Ph.D.

Takao Koike, M.D., Ph.D.

Hokkaido University Graduate School of Medicine

Sapporo 060-8638, Japan

tbohgaki@uhnres.utoronto.ca

1. Farge D, Passweg J, van Laar JM, et al. Autologous stem cell transplantation in the treatment of systemic sclerosis: report from the EBMT/EULAR Registry. Ann Rheum Dis 2004;63:97481.

2. de Kleer I, Vastert B, Klein M, et al. Autologous stem cell transplantation for autoimmunity induces immunologic selftolerance by reprogramming autoreactive $\mathrm{T}$ cells and restoring the CD4+CD25+ immune regulatory network. Blood 2006;107: 1696-702.

3. King C, Ilic A, Koelsch K, Sarvetnick N. Homeostatic expansion of $\mathrm{T}$ cells during immune insufficiency generates autoimmunity. Cell 2004;117:265-77.

4. Bettelli E, Carrier Y, Gao W, et al. Reciprocal developmental pathways for the generation of pathogenic effector TH17 and regulatory T cells. Nature 2006;441:235-8.

5. Bettelli E, Oukka M, Kuchroo VK. T(H)-17 cells in the circle of immunity and autoimmunity. Nat Immunol 2007;8:34550. 